В статье на основе архивных и опубликованных источников рассматриваются основные этапы эволюции художественных объединений Российской империи первой половины середины XIX в., оказавших влияние на становление Товарищества передвижных художественных выставок в 1870 г. Опровергается устоявшаяся в историографии точка зрения, в рамках которой образование Товарищества художников-передвижников рассматривается как прямое следствие «бунта четырнадцати» 1863 г. Делается вывод о том, что объединение передвижников явилось результатом аккумулирования сил и идей московских и петербургских художественных объединений предыдущих десятилетий XIX столетия.

Ключевые слова: Товарищество передвижных художественных выставок, Академия художеств, «бунт четырнадцати», художественные объединения, интеллигенция, искусство.

\author{
N.Yu. Kolokolceva, K.V. Valkova
}

\title{
THE INFLUENCE OF ARTISTIC INTELLIGENTSIA ASSOCIATIONS OF 1820-1860s ON FORMATION OF THE SOCIETY FOR CIRCULATING ART EXHIBITIONS
}

\begin{abstract}
The article examines the main stages of the evolution of the art associations of the Russian Empire in the first half - the middle of the 19th century, which influenced the formation of the Society for Circulating Art Exhibitions in 1870, taking into consideration archival material and published sources. The view established in historiography, in which the formation of the Association of Travelling Artists is considered as a direct consequence of the "riot of fourteen" in 1863. It is concluded that the association of the Itinerants was the result of the unification of forces and ideas of Moscow and St. Petersburg art associations of the previous decades of the 19th century.

Key words: the Society for Circulating Art Exhibitions, Academy of Arts, «riot of fourteen», art associations, intelligentsia, art.
\end{abstract}

Изучение деятельности объединений творческой интеллигенции, с точки зрения их роли и места в развитии российского общества и его культуры, не теряет своей актуальности. Перемены политической ситуации в стране оказывают прямое влияние на деятельность художественной интеллигенции, которая через искусство выражает свою гражданскую позицию. Художественные образы - это результат как личностной, так и коллективной рефлексии. Историческое сознание формируется под влиянием изменяющейся ситуации. Пики развития культуры совпадают с переломными историческими моментами. Наиболее показательным в этом плане является образованное в 1870 г. Товарищество передвижных художественных выставок, игравшее не одно десятилетие решающую роль в диалоге власти и общества. Научная новизна исследования заклю- чается в том, что авторы отходят от доминирующей в историографии точки зрения, напрямую связывающей создание Товарищества художников-передвижников с «бунтом четырнадцати» 1863 г. и образованием Санкт-Петербургской артели художников, и прослеживают предпосылки создания объединения с образования Общества поощрения художников в 1820 г.

Историография темы немногочисленна и представлена исследованиями советского периода по искусствоведению и истории культуры. Большой интерес представляют работы Ф.С. Рогинской, автор рассматривает передвижников в контексте деятельности разночинной художественной интеллигенции и находит предпосылки к становлению Товарищества в революционной ситуации рубежа 1850-1860-х гг. $[1,2]$. Не меньшего внимания заслуживают исследования Д.В. Сара- 
бьянова, который выделил два источника (по названию столиц) в искусстве $1860-$ х гг., приведших к образованию Товарищества передвижных художественных выставок [3, 4]. Анализ историографии позволяет говорить о не изученности темы историками, а также о рассмотрении создания Товарищества художников-передвижников вне исторического контекста первой половины XIX в.

Методологической основой исследования является многолинейная модель теории модернизации, где главная роль в процессе изменений принадлежит социальным акторам (индивидам и коллективам), а не анонимным законам эволюции $[5$, с. 156]. Историчность подхода и отказ от принципа системной трансформации позволяют решить задачи данного исследования. Товарищество передвижных художественных выставок как результат эволюции объединений художественной интеллигенции первой половины - середины XIX в. соответствует постулатам данной теории.

Сложность изучаемого предмета, находящегося на стыке нескольких наук, определила выбор применяемых методов. Системный метод является одним из ключевых, так как позволяет рассмотреть Товарищество передвижных художественных выставок в системе общественных и государственных институтов России XIX в. Также большое значение сыграли историко-генетический, историко-хронологический и историко-типологический методы. Особое место занял просопографический метод, который позволяет раскрыть суть изучаемого исторического периода через рассказ о лицах и объединениях, судьбы и деяния которых тесно связаны с соответствующими учреждениями и явлениями [6, с. 642-643].

Изучение становления Товарищества передвижных художественных выставок потребовало привлечения широкого круга источников. Основу работы составили источники личного происхождения (дневники, мемуары, переписка и т. д.) и официальные документы (уставы, протоколы). Среди опубликованных источников особый интерес при изучении данной проблемы представляют письма И.Н. Крамского [7, 8] и Г.Г. Мясоедова [9], благодаря которым можно подробно проследить процесс объединения Московской и Петербургской художественных школ в Товарищество передвижных художественных выставок. В статье вводятся в научный оборот материалы секретного архива III Отделения Собственного Его Императорского Величества канцелярии «О создании Товарищества передвижных художественных выставок в 1864 г.», хранящиеся в Государственном архиве Российской Федерации (ГАРФ) [10].
Анализ данных материалов позволяет говорить о том, что еще в 1860-х гг. независимыми художественными объединениями были приняты первые попытки выйти на провинциальный художественный рынок. Важную группу источников составили справочно-информационные издания. В справочнике Д.Я. Северюхина, О.Л. Лейкинда [11] систематизирована информация по независимым художественным объединениям России 1820-1932 гг., позволяющая выявить основные тенденции в развитии общественных структур изучаемого периода. Комплексное использование материалов и методов позволило решить задачи данного исследования.

XIX век в России неминуемо должен был «разрешиться» новой формой художественной деятельности, которой в 1870 г. стало Товарищество передвижных художественных выставок. Наиболее ранним объединением, оказавшим заметное влияние на становление передвижничества, стало основанное в 1820 г. в Санкт-Петербурге Общество поощрения художников. Задачи общества включали содействие успехам изящных искусств в России, а также одобрение и поощрение дарования русских художников. Благодаря выделению значительных материальных средств на поддержку талантливой молодежи многие из будущих передвижников, стесненных в деньгах, не оставили занятий живописью. В разное время пособия получили бывшие в то время учениками Академии художеств И.Н. Крамский, М.К. Клодт, М.П. Клодт, К.Ф. Лемох, К.Е. Маковский и др. [11, c. 178].

В Москве первое независимое объединение «Московское художественное общество» возникло в 1832 г. Основой общества стал Натурный кружок художников и любителей, собиравшихся на квартире выпускника Академии художеств А.С. Ястребилова для совместного рисования, а также организации временных выставок. В 1843 г. при объединении открылось Московское училище живописи, ваяния и зодчества, развитие которого стало главной задачей общества. Концентрация в Училище лучших художественно-педагогических сил Москвы позволила ему соперничать с Академией художеств, многие передвижники являлись выпускниками заведения [11, c. 135-137].

Отметим, что, несмотря на формальную независимость, первые художественные объединения находились под покровительством, а следовательно, и полным контролем со стороны императорской власти. В состав обществ входили в основном меценаты из числа высокопоставленных 
государственных чиновников и аристократов. Только на рубеже 1850-1860-х гг. наблюдается определенная либерализация в объединениях. Так, устав 1857 г. Общества поощрения художников позволил демократизировать состав посредством введения нового статуса члена-соучастника без права решающего голоса. Принятие данного положения способствовало резкому численному увеличению общества, превысившему к началу 1880-х гг. 750 человек. Среди членов-соучастников были и передвижники А.К. Беггров, А.П. Боголюбов, Н.Н. Ге и А.И. Куинджи, привнесшие новое видение задач, стоящих перед обществом [11, c. 179]. В Московском художественном обществе, благодаря усилиям основателей Товарищества В.Г. Перова, И.М. Прянишникова, А.К. Саврасова, в 1860-е гг. усиливается влияние реалистического направления [11, с. 135-137].

Период второй половины XIX в. характеризуется количественным и качественным ростом общественных объединений в России, что во многом определялось политической ситуацией в стране. Конфликты и общественные противоречия первой половины столетия усилились после поражения России в Крымской войне, а первые либеральные реформы Александра II не привели к желаемым результатам.

Образованные в 1850-е гг. художественные объединения принимают новый окрас. Так, в 1857 г. учащиеся и выпускники Академии художеств попытались организовать два объединения. Первым явилось Художественное общество в Императорской Академии художеств с целью распространения в обществе любви к искусству, а также взаимного обмена идеями, относящимися к сфере художеств. Из будущих передвижников в состав учредителей входили Г.Г. Мясоедов, К.Ф. Гун, А.Д. Литовченко. Несмотря на то, что идеи общества нашли поддержку в лице Президента Академии Художеств великой княгини Марии Николаевны, основной реакцией стал протест. Представители власти опасались, что объединение молодежи средних и низших сословий может принять «нежелательное направление». Основываясь на этой точке зрения, император Александр II отклонил утверждение устава общества, после чего постановлением от 19 марта 1858 г. оно было закрыто [11, с. 137].

После неудавшейся попытки организации Художественного общества были созданы Академические пятницы. Изначально «пятницы» устраивались поочередно на квартирах их участников, среди которых и будущие передвижники А.К. Беггров, А.П. Боголюбов, М.К. Клодт и др.
С января 1860 г. «пятницы» стали устраиваться в залах Академии художеств, отсюда и название «академические». В этом же году происходит увеличение числа их участников и усложнение организационной структуры. Члены кружка стали выпускать альбом литографий под названием «Русские художники», доход с продажи которых шел на помощь нуждающимся. Возрос и капитал «Пятниц», состоящий из членских взносов и доходов от продажи рисунков, который использовался для выдачи ссуд нуждающимся художникам. Интересно, что наравне с художниками «пятницы» посещали актеры, музыканты, литераторы, а также учащиеся, но с разрешения старосты, который руководил общим ходом вечеров. В конце 1862 г. между участниками «пятниц» и руководством Академии возник конфликт, в ходе которого руководство предложило заменить избираемых старост назначаемыми, что не соответствовало убеждениям членов общества. В результате объединение самораспустилось [12, л. 126].

В Москве в это время решающее значение играло открытое в 1860 г. Московское общество любителей художеств, в задачи которого среди прочего входило посредством сближения любителей искусства (меценатов) с художниками положить основание Московской Публичной художественной галереи. Не случайно почетными членами Общества выступили и братья П.М. и C.M. Третьяковы. В основе деятельности объединения была организация постоянной, периодически обновляемой выставки, на которой московская публика впервые увидела картины нового художественного направления, в том числе полотно Н.Н. Ге «Тайная вечеря» (1863 г.). Организация выставок показала, что в Москве преобладал демократически настроенный зритель, стремившийся увидеть в искусстве правдивое отображение действительности [3, с. 34]. Одновременно с Товариществом в 1870 г. при Московском обществе открылись бесплатные для его членов рисовальные классы, в числе руководителей которых были и передвижники В.Г. Перов и И.М. Прянишников. Преподавание в данном обществе позволило впоследствии знакомить молодое поколение художников с идеями Товарищества, пополняя, таким образом, ряды объединения талантливой молодежью [11, с. 130-132].

Несмотря на то, что роль художников в организациях этого времени значительно возрастает, их деятельность по-прежнему четко регламентировалась и не могла выходить за рамки академических устоев. Можно сказать, что Академия художеств в этот период времени являлась анах- 
ронизмом пореформенной России [13, л. 106]. Причем в Санкт-Петербурге это давление было намного больше. Это не могло не вызвать противодействия со стороны прогрессивной художественной интеллигенции, вылившееся в «бунте четырнадцати» 9 ноября 1863 г., когда одни из самых талантливых художников вышли из Академии после получения отказа со стороны руководства писать картины на самостоятельно выбранные темы. Отметим, что в некоторых источниках он упоминается как «бунт тринадцати» $[14$, с. 229], т. к. один из подписавших прошение П. Заболотский в итоге заявил о намерении участвовать в конкурсе и не покинул стены Академии. Однако вместо него прошение о выходе поступило от скульптора В.П. Крейтана, в итоге Академию покинули четырнадцать человек - тринадцать художников и один скульптор. Тот факт, что руководство Академии кроме стандартного мифологического сюжета предложило и вторую тему освобождение крестьян, позволяет говорить, что художники выступали не против конкретной темы, а против самого принципа навязывания и ограничения самостоятельности $[1$, с. 10], что, в свою очередь, можно рассматривать как проявление духа либерализма, который завоевывал Россию в XIX в.

Выступление против академических устоев вызвало сочувствие и поддержку в кругу художественной интеллигенции. Однако художники, боясь, что Академия откажется выдать им дипломы, не разглашали подробности конфликта $[7$, с. 50]. Тем не менее информация просочилась в прессу, часто выставляя бывших учеников Академии не в лучшем свете. В частности, события 9 ноября 1863 г. упоминались в газете «Современная летопись. Воскресные прибавления к Московским ведомостям» в статье историка искусств, академика Императорской академии художеств Н.А. Рамазанова. Автор называет поступок учеников Академии «демонстрацией, достойной сожаления», а самих художников «петербургскими крикунами, ратующими против старого академического образования». В качестве виновных в организации протеста Н.А. Рамазанов видит «петербургских журнальных и газетных повстанцев против Академии, которые, используя дух бесполезного подстрекательства, сбивают с толку легкомысленную и неопытную молодежь» $[15$, с. 448]. Тем самым автор ставит события в Академии в один ряд с антиправительственными выступлениями молодежи тех лет. Участники «бунта» были крайне возмущены статьей, написанной по слухам, тем более что назвать их поступок «демонстрацией», означало указать правительству на них пальцем, учитывая и без этого пристальное внимание [7, c. 53]. Таким образом, выход из Академии угрожал ее ученикам не только материальной нуждой, объяснявшейся отсутствием свободного художественного рынка в России, но и политическим недоверием со стороны властей $[8$, с. 6].

Тринадцать участников «бунта четырнадцати»: И.Н. Крамской, Б.Б. Вениг, А.К. Григорьев, Н.Д. Дмитриев-Оренбургский, Ф.С. Журавлев, А.И. Корзухин, К.В. Лемох, К.Е. Маковский, А.И. Морозов, М.И. Песков, Н.П. Петров, Н.С. Шустов и скульптор В.П. Крейтан, понимая сложность своего дальнейшего существования, решили образовать художественную ассоциацию с совместным проживанием [7, с. 50]. Идейным вдохновителем стал И.Н. Крамской. Изначально предполагалось именоваться «художественным комиссионерством» и выступать от одного лица $[7$, c. 51$]$.

3 января 1864 г. в типографии Императорской Академии наук было отпечатано объявление о приеме к исполнению следующих видов художественных заказов: образов; иконостасов; стенной живописи; копий с картин, фотографических и дагерротипных портретов в различную величину; портретов с натуры масляными красками, акварелью, постелью, карандашом; сочинение рисунков и виньеток для изданий, журналов и альбомов; рисунков для изделий из серебра, бронзы и других металлов; а также скульптурных произведений: барельефов, круглых фигур, бюстов, орнаментов и рисунков для памятников и каминов. Кроме того, предлагалось давать уроки рисования, живописи и скульптуры на дому или в своих мастерских [10, л. 1-2].

Примечательно, что объединение именовалось Передвижным товариществом художников и имело только коммерческие цели. Подобное название объяснялось тем, что живописцы, открыв свое общество в обеих столицах, планировали постепенно охватить всю Россию [7, с. 51]. Отметим, что закрепленное за объединением участников «бунта четырнадцати» в историографии название «Санкт-Петербургская артель художников» формально появилось только в 1865 г. [16, с. 50-51]. Заказчиков в Санкт-Петербурге, где постоянно проживали все члены объединения, просили обращаться в квартиры доходных домов № 4 Гудкова (17-я линия Васильевского острова, дом 4) [17, c. 191] и № 1 Струкова (Английская набережная, дом 54) $[17$, с. 8]. В Москве нужно было обращаться в дом № 17 Тверского подворья на Кузнецком мосту в фотографическое заведение художника 
М.Б. Тулинова [18, с. 59]. Тулинов, земляк и близкий друг И.Н. Крамского, фактически стал посредником между художниками и заказчиками в Москве.

Объединяясь, художники не имели первоначального капитала, собрать который предполагалось в течение первых пяти лет посредством внесения части дохода с заказов. В целях экономии предполагалось жить всем вместе и работать в имеющихся общих мастерских [7, с. 52]. Отсутствие финансовой поддержки со стороны меценатов, а также пристальное внимание к объединению со стороны III Отделения Собственной Его Императорского Величества канцелярии, усматривавшей основную цель Товарищества в противоборстве с Академией художеств [10, л. 1], значительно осложняли его деятельность в первые годы. Тексты объявлений художников о приеме заказов подвергались жесткому контролю со стороны властей, т. к. еще 9 ноября 1863 г. вицепрезидент Г.Г. Гагарин просил начальника III Отделения В.А. Долгорукова не допускать к печати никакой информации, связанной с участниками «бунта» без его предварительного просмотра [7, c. 50].

В середине 1864 г. в Петербурге была создана Артель П.А. Крестоносцева (Волгина), в состав которой вошли будущие художники-передвижники А.А. Киселев и В.М. Максимов $[19$, с. 51]. Артель имела схожие цели с объединением участников «бунта четырнадцати», что делало их соперниками на художественном рынке. Крамской отмечал, что «на их беду возникло еще подобное общество художников, вооруженное всеми средствами, т. е. возможностью нанимать квартиру в хорошей части города и тратить большую сумму денег для публикаций объявлений» [7, с. 54]. Летом следующего года Артель Крестоносцева распалась из-за материальных трудностей. П.А. Крестоносцев и Н.А. Кошелев вошли в Санкт-Петербургскую артель художников [11, с. 13].

Отметим, что создание артелей с совместным проживанием было широко распространено в среде разночинной интеллигенции 1860-х гг. Члены артелей активно интересовались вопросами политики и культуры $[1$, с. 11], что позволяет говорить о формировании особого типа художника-шестидесятника. И.Н. Крамской, понимая, что организованная для улучшения материального благосостояния живописцев Артель не могла в художественном плане противостоять Академии, попытался создать Клуб художников. Цель Клуба - развитие самобытной русской реалистической художественной школы, поддерж- ка талантливой молодежи в финансовом плане и организация собственной живописной школы [14, с. 172-173]. Отметим, что первая попытка создания подобного клуба была предпринята участниками Академических пятниц еще в 1963 г. Тогда устав Клуба был отвергнут Министерством внутренних дел, в связи с избытком различных клубов в Петербурге [11, с. 260]. Идея Крамского получила широкую поддержку, однако образованное в конечном итоге объединение свелось к организации семейных вечеров, не имеющих ничего общего с первоначальными задачами Клуба, поэтому художников в его составе практически не было [14, с. 174-175].

Объединение художников во главе с И.Н. Крамским ставило основной своей целью выход на неосвоенный провинциальный рынок. Художники готовы были принимать заказы со всех концов России, однако финансовая ограниченность не позволяла на должном уровне развернуть рекламную кампанию в местных газетах [7, с. 55]. В марте 1865 г. совместно с Артелью Крестоносцева в Нижнем Новгороде была организована выставка современных и старых мастеров, ставшая прообразом передвижных выставок $[11$, c. 256]. Еще одной нереализованной задачей Артели была организация постоянной выставки с бесплатным входом, что позволило бы заявить о себе и произносить через свои картины приговор окружающей их действительности $[7$, c. 55].

Примерно к 1868 г. Артели удалось завоевать московский и петербургский художественный рынок, перейти в более просторную квартиру на углу Адмиралтейской площади и Вознесенского проспекта [14, с. 175]. Скопив приличный капитал, художники купили фотоаппарат и задумались об открытии отделения Артели в Москве, где основным заказчиком портретов являлся П.М. Третьяков [7, с. 57-59]. Однако вскоре из-за финансовых конфликтов среди артельщиков объединение начало распадаться.

На рубеже $1860-70$-х гг. для художников-реалистов становится очевидна необходимость новой формы организации, позволяющей напрямую контактировать с простым зрителем [2, с. 5]. Идея создания подобного объединения принадлежала Г.Г. Мясоедову, поставившему перед собой задачу объединить московскую и петербургскую живописные школы [3, с. 51]. Подобное объединение привело к слиянию двух источников, без которых широкая популяризация искусства была на тот период времени невозможна. Первый источник - идейно-организационный, представленный Санкт-Петербургской артелью художников, 
второй - идейно-творческий, представленный московскими объединениями художников-жанристов $[4$, с. 78$]$.

23 ноября 1869 г. в адрес Артели поступило письмо с проектом устава Товарищества подвижной выставки, подписанное московскими художниками Г.Г. Мясоедовым, В.Г. Перовым, Л.Л. Каменевым, А.К. Саврасовым, И.М. Прянишниковым и И.М. Шервудом [9, с. 63]. На доведение устава до совершенства ушел практически год. В итоговом варианте формулировка «подвижные выставки» была заменена на использовавшуюся ранее - «передвижные выставки». Опасаясь отказа в регистрации Товарищества, московские члены нашли возможность отправить письмо на имя жены министра внутренних дел А.Е. Тимашева с просьбой обратить внимание на устав художников-передвижников. В результате Товарищество передвижных художественных выставок было зарегистрировано 23 ноября 1870 г., закрепив в своем уставе основные достижения и идеи худо- жественных объединений предшествующих десятилетий XIX столетия [20, л. 1 об.]

Подводя итоги, отметим, что в XIX в. художественная интеллигенция прошла несколько этапов своего структурного развития: от зачатков самостоятельных организаций, объединенных схожим художественным вкусом и выражавших общественные и нравственные принципы тех или иных групп художников, до официально оформленных независимых профессиональных организаций, каким стало Товарищество передвижных художественных выставок. Именно оно аккумулировало в себе основные художественные силы и тенденции объединений творческой интеллигенции первой половины - ceредины XIX в. В итоге возникло независимое от официальной художественной школы и средств меценатов объединение, совершенно новое по своим установкам, соединившее просветительские задачи с задачами реалистического познания современной жизни.

\section{Библиографический список}

1. Рогинская Ф. С. Товарищество передвижных художественных выставок: исторические очерки. М.: Искусство, 1989. 430 с.

2. Рогинская Ф. С. Передвижники. М.: Искусство, 1993. 183 с.

3. Сарабьянов Д. В. История русского искусства второй половины XIX века. М.: Изд-во МГУ, 1989. 384 с.

4. Сарабьянов Д. В. Передвижники и их предшественники // Передвижники: сборник статей / ред. И.М.Гофман. М.: Искусство. С. 68-82.

5. Побережников И. В. Модернизация: теоретико-методологические подходы // Экономическая история. Обозрение / под ред. Л. И. Бородкина. М., 2002. Вып. 8. С. 146-168.

6. Петрова М. С. Просопография как метод исторического исследования: Макробий Феодосий и Марциан Капелла // История через личность: Историческая биография сегодня / под ред. Л. П. Репиной. М.: Квадрига, 2010. С. 641-703.

7. Иван Николаевич Крамской: Его жизнь, переписка и художественно-критические статьи 1837-1887 / сост. А. С. Суворин. СПб.: Тип. А. С. Суворина, 1888. 750 с.

8. Стасов В.В.Крамской об искусстве. М.: Изобразительное искусство, 1988. 176 с.

9. Мясоедов Г. Г. Письма, документы, воспоминания. М.: Изобразительно искусство, 1972. 328 с.

10. Государственный архив Российской Федерации (ГАРФ). Ф. 109. Оп. 1а. Д. 1098.

11. Золотой век художественных объединений в России и СССР / сост. Д. Я. Северюхин, О. Л. Лейкинд. СПб.: Изд-во Чернышева, 1992. 400 с.

12. Российский государственный исторический архив (РГИА). Ф. 789. Оп. 4, 1863. Д. 5.

13. Российский государственный архив литературы и искусств (РГАЛИ). Ф. 2711. Оп. 4. Д. 9.

14. Репин И. Е. Далекое близкое. М.: Академия художеств СССР, 1961. 510 с.

15. Рамазанов Н. А. Материалы для истории художеств в России: статьи и воспоминания / сост. Н. С. Беляев. СПб.: БАН, 2014. 784 с.

16. Аполлон. Изобразительное и декоративное искусство. Архитектура: терминологический словарь / общ. ред. А. М. Кантор. М.: Эллис Лак, 1997. 736 с.

17. Описание улиц С.-Петербурга и фамилий домовладельцев к 1863 году / сост. Н. Цылов. СПб.: Тип. т-ва «Общественная польза», 1862. 458 с.

18. Дроздов Д. П. «Китай-город», «Лубянка», «Театральная», «Арбатская». Пешеходные прогулки в окрестностях метро. М.: Центрполиграф, 2017. 250 с.

19. Леонов А. И. Василий Максимович Максимов: Жизнь и творчество. М.: Искусство, 1951. 351 с.

20. Отдел рукописей Государственной Третьяковской галереи (ОР ГТГ). Ф. 69. Оп. 1. Д. 2. 